\title{
Klasa bezpieczeństwa i wymagania ASME i RCC-M dotyczące armatury i rurociągów podczas budowy pierwszej elektrowni jądrowej w Polsce
}

\author{
Safety class and requirements of ASME and RCC-M \\ codes for valves and piping during the building \\ of the first nuclear power plant in Poland
}

\section{Streszczenie}

Krótko scharakteryzowano armaturę i rurociągi w elektrowniach jądrowych oraz ich podział na klasy bezpieczeństwa w oparciu o zalecenia IAEA oraz wymagania przepisów ASME i RCC-M.

Słowa kluczowe: elektrownia jądrowa; rurociąg; klasa bezpieczeństwa; spawanie; ASME; RCC-M

\section{Abstract}

Piping systems in nuclear power plants (NPPs) and their safety class classification acc. to IAEA Safety Standards and requirements of ASME and RCC-M codes are shortly presented.

Keywords: nuclear power plant; piping; safety class; welding; ASME; RCC-M

\section{Wprowadzenie}

Rurociągi technologiczne (piping) oraz towarzysząca im armatura w każdym zakładzie przemysłowym są niczym układ krwionośny w ciele człowieka. Dzięki instalacjom rurowym o różnym przeznaczeniu składającym się z rur, wsporników lub zawieszeń (pipe suport systems) oraz zaworów (valves) i pomp (pumps) możliwa jest praca zarówno prostych urządzeń technicznych, jak i skomplikowanych zakładów produkcyjnych w wielu dziedzinach gospodarki, w tym energetyce jądrowej. Układy rurowe są przeznaczone głównie do transportu gazu, pary lub cieczy oraz pracują w bardzo różnych warunkach środowiskowych, często w atmosferach lub środowiskach silnie korozyjnych. Rurociągi i odpowiednia armatura powinny ponadto zapewniać niezawodną pracę urządzeń technologicznych przy skrajnie różnych parametrach, $\mathrm{np}$. w temperaturach ujemnych lub podwyższonych, przy oddziaływaniu podwyższonego ciśnienia (nadciśnienie) lub w próżni (podciśnienie). W związku z dużym znaczeniem instalacji rurociągowych w każdym układzie produkcyjnym, zasady ich projektowania, wytwarzania i odbioru podlegają znormalizowaniu, np. w oparciu o wymagania PED, ASME lub norm serii EN, EN ISO, API, NORSOK itd., co zależy od branży przemysłowej oraz kraju, w którym te rurociągi i armatura będą eksploatowane.

Elektrownia jądrowa jest szczególnym obiektem przemysłowym. Specyfika jej pracy polega na tym, że do wytwarzania pary zasilającej turbinę, która generuje prąd elektryczny, stosuje się ciepło powstające w wyniku przebiegu reakcji jądrowej (rozszczepiania jąder atomowych). Fakt ten powoduje, że zasady projektowania, wytwarzania i odbioru urządzeń, rurociągów i armatury, które są istotne z punktu widzenia bezpieczeństwa jądrowego, są ujęte w specjalnych przepisach i normach, w tym m.in. w przepisach ASME Section III [1] lub AFCEN RCC-M [2]. Poniżej przedstawiono krótką charakterystykę instalacji rurociągowych $\mathrm{w}$ niektórych aktualnie budowanych na świecie elektrowniach jądrowych oraz omówiono ich klasyfikacje w zależności od wpływu na bezpieczeństwo.

\section{Klasyfikacja rurociągów i armatury w elektrowniach jądrowych}

Jak już wspomniano, elektrownia jądrowa jest szczególnym obiektem technicznym, w którym wiele podstawowych urządzeń i układów technologicznych powinny zapewniać bezpieczną pracę w obecności źródła promieniowania. Niektóre układy elektrowni nie mają jednak wpływu na bezpieczeństwo jądrowe, np. wiele zbiorników, rurociągów, zaworów i pomp wyspy turbinowej (konwencjonalnej).

Dr inż. Jerzy Niagaj, prof. nzw., IWE - Instytut Spawalnictwa.

Autor korespondencyjny/Corresponding author. Jerzy.Niagaj@is.gliwice.pl 
W związku z powyższym rozróżnia się dwie główne grupy konstrukcji, układów (systemów) i komponentów elektrowni jądrowych (structures, systems and components (SSC)): związane z bezpieczeństwem jądrowym (safety-related) i niezwiązane z tym bezpieczeństwem (non safety-related). W języku angielskim ostatnia grupa urządzeń i układów może być także opisywana jako: non-nuclear lub non-Code lub No Class lub unclassified lub Non-Safety (NS) lub Not Classified (NC).

Urządzenia i układy technologiczne elektrowni jądrowych zaliczane do grupy związanej z bezpieczeństwem jądrowym nie zawsze pełnią jednak podobne funkcje oraz pracują w takich samych warunkach, a co za tym idzie, mogą stwarzać podobne ryzyko. W związku z powyższym wszystkie kody i przepisy jądrowe, w tym ww. ASME i AFCEN, zawierają wymagania w zakresie projektowania, wytwarzania i odbioru urządzeń ciśnieniowych, układów rurociągowych i armatury w zależności od klasy bezpieczeństwa (safety-related classification). W chwili obecnej przepisy działające w większości krajach posiadających elektrownie jądrowe zakładają podział na trzy klasy bezpieczeństwa: Class 1, 2 oraz 3, gdzie Class 1 obejmuje SCC, których awaria może wywołać najbardziej poważne skutki dla osób i otoczenia. W niektórych krajach może wystąpić inne oznaczenie klas bezpieczeństwa lub inna ich ilość, ale zdarza się to rzadko. Tak w Finlandii do 2013 roku istniał podział na cztery klasy bezpieczeństwa Class 1, 2, 3, 4 oraz Class EYT (dla konwencjonalnych urządzeń ciśnieniowych). Podstawą takiej klasyfikacji były wcześniejsze wytyczne International Atomic Energy Agency (IAEA). Podział na cztery klasy, a nie trzy, jak w ASME lub AFCEN, powodował określone trudności praktyczne. W 2013 roku przepisy fińskie zostały zaktualizowane w taki sposób, że obecny podział na klasy bezpieczeństwa w Finlandii jest podobny do rekomendowanego przez nowe wytyczne IAEA oraz stosowanego w ASME Section III i AFCEN RCC-M, a mianowicie: Class 1, 2, 3. Klasa EYT (non-nuclear safety), podobnie jak wcześniej, dotyczy konwencjonalnych urządzeń ciśnieniowych [3].

Strukturę i metodę (porady i wskazówki) w zakresie identyfikacji i klasyfikacji struktur, układów i komponentów (SSC) istotnych z punktu widzenia bezpieczeństwa na podstawie ich funkcji i znaczenia dla bezpieczeństwa opisano w wytycznych IAEA Safety Standards Series No. SSG-30 [4], które odwołują się z kolei do dokumentów IAEA Safety Standards Series No. SSR-2/1 (Rev. 1) [5] oraz IAEA Safety Standards Series No. SGR Part 4 (Rev. 1) [6] zawierających opis wymagań. Celem wytycznych IAEA jest zapewnienie wysokiego poziomu bezpieczeństwa poprzez spełnienie odpowiednich wymogów jakościowych oraz niezawodności obiektów. Zasady projektowania inżynieryjnego elementów ważnych dla bezpieczeństwa w elektrowni jądrowej muszą być określone i zgodne z odpowiednimi przepisami i normami krajowymi lub międzynarodowymi oraz stosować sprawdzone rozwiązania techniczne, z należytym uwzględnieniem ich przydatności do technologii jądrowej.

Przy opracowywaniu projektu, dostawca technologii jądrowej klasyfikuje poszczególne układy, struktury i komponenty (SSCs) do odpowiedniej klasy bezpieczeństwa jądrowego. W tym miejscu należy nadmienić, że kody jądrowe ASME lub RCC-M nie klasyfikują urządzeń i układów wg klas bezpieczeństwa jądrowego, lecz tylko formułują wymagania w ramach każdej z tych klas. Wyjątek stanowi Class 1, która zawsze obejmuje urządzenia i rurociągi układu chłodzenia rdzenia reaktora, w tym bezpośrednio reaktor jądrowy, wytwornice pary, stabilizator ciśnienia, główną pompę cyrkulacyjną układu chłodzenia, główne rurociągi itd.

W Polsce w rozporządzeniu Ministra Rozwoju z dnia 20 maja 2016 r. w sprawie warunków technicznych dozoru technicznego dla urządzeń technicznych lub urządzeń podlegających dozorowi technicznemu w elektrowni jądrowej (Dz. U. z 2016 r. poz. 909) w § 4.1. wskazuje się, że "do urządzeń EJ należących do odpowiedniej klasy bezpieczeństwa stosuje się wymagania techniczne określone w dokumentach odniesienia mających zastosowanie do tych urządzeń, o ile przepisy rozporządzenia nie stanowią inaczej". Z kolei wg § 4.2. stwierdza się, że „do urządzeń EJ, dla których nie określono klasy bezpieczeństwa, stosuje się wymagania zawarte w normach technicznych właściwych dla danych urządzeń oraz w innych specyfikacjach technicznych dotyczących wymagań projektowych, o ile przepisy niniejszego rozporządzenia nie stanowią inaczej".

W związku z powyższym, podczas budowy pierwszej elektrowni jądrowej w Polsce będą stosowane te przepisy, w oparciu o które opracowano jądrowe urządzenia i układy technologiczne zwycięzcy przetargu. Wśród najbardziej prawdopodobnych uczestników przetargu wymienia się firmy: AREVA (EPR ${ }^{\mathrm{TM}}$ ), Hitachi GE (ABWR) oraz Westinghouse (AP1000). A zatem wymagania w zakresie projektowania, wytwarzania i odbioru urządzeń, struktur i komponentów, w tym rurociągów i armatury, związanych z bezpieczeństwem jądrowym będą oparte o wymagania odpowiednich sekcji kodów AFCEN RCC-M oraz ASME Section III, które zakładają podział na klasy bezpieczeństwa: Class 1, 2 oraz 3.

\section{Krótka charakterystyka instalacji rurowych w elektrowniach jądrowych}

W elektrowniach jądrowych rurociągi, komponenty rurowe i armatura mogą być wykonane $\mathrm{z}$ różnych materiałów, $\mathrm{np}$. stale niestopowe, stale nierdzewne, stopy niklu, tytanu lub cyrkonu, a ich średnica mieścić się w zakresie od kilku milimetrów do nawet 2,4 m. Równie szeroki jest także zakres funkcji, które układy rurociągowe pełnią. Instalacje rurowe są m.in. nieodłączną częścią składową układów, zespołów lub systemów:

- chłodzenia reaktora;

- odprowadzania ciepła resztkowego;

- kontroli chemicznej i ilości wody;

- chłodzenia urządzeń wyspy jądrowej niezwiązanych z bezpieczeństwem;

- chłodzenia i oczyszczania wody basenu zużytego paliwa;

- wymiany ciepła w wytwornicach pary;

- zraszania wnętrza obudowy bezpieczeństwa;

- wody technicznej (lub morskiej);

- demineralizacji wody;

- pary świeżej;

- skraplacza i innych urządzeń wyspy turbinowej;

- powrotu schłodzonej wody;

- powietrza;

- zasilania azotem;

- olejowych turbiny;

- chłodzenia i zasilana w paliwo awaryjnych silników diesla;

- filtrowentylacyjnych;

- przeciwpożarowych

- oraz wielu, wielu innych.

W zależności od typu reaktora, jego mocy oraz dostawcy technologii jądrowej, łączna długość rurociągów może istotnie różnić się. Z informacji prasowych oraz publikacji technicznych wynika, że w przypadku budowy jednego bloku o mocy od 1100 do 1600 MWe łączna długość rurociągów mieści się w zakresie od 70 do $150 \mathrm{~km}[7 \div 9]$. W przypadku zaworów szacuje się z kolei, że w zależności od technologii jądrowej ich ilość może wynosić od 18 do 30 tysięcy. 
Rury są stosowane nie tylko do budowy instalacji rurociągowych, lecz również stanowią istotna część takich urządzeń jak wymienniki ciepła i generatory pary. W zależności od konstrukcji wytwornicy pary łączna długość rurek mieści się w zakresie od 75 do $220 \mathrm{~km}$, a do ich produkcji stosuje się różne gatunki stopów niklu, z których najczęściej stosowanym jest Alloy 690 (UNS N06690). Średnica używanych w wytwornicach rurek waha się w zakresie od 14 do $25 \mathrm{~mm}$, a grubość ścianki od 0,5 do 1,3 mm. Przykładowo, wytwornica pary dostarczona z zakładu w Chalon (Francja) na elektrownie jądrową Olkiluoto 3 (Finlandia) zawiera 6000 rurek o łącznej długości 140 km [10]. Rurki te są wykonane ze stopy niklu Alloy 690 TT oraz cechują się średnicą 19,05 mm i grubością ścianki 1,09 mm.

Poniżej przedstawiono ogólną charakterystykę układów rurowych w elektrowniach jądrowych z reaktorami EPR ${ }^{\mathrm{TM}}$, AP1000 oraz ABWR, z których jeden może zostać zainstalowany w Polsce w zależności od wyników planowanego w najbliższym czasie przetargu.

\section{EPR $^{\text {TM }}$}

W zależności od miejsca budowy elektrowni z reaktorem $\mathrm{EPR}^{\mathrm{TM}}$ oraz źródła danych, łączna długość rurociągów w przypadku pojedynczego bloku wynosi od 100 do $120 \mathrm{~km}$ [11], a ilość mocujących ich wsporników i zawieszeń (supports) kształtuje się na poziomie 35 tysięcy. Większość orurowania jest zlokalizowana w wyspie jądrowej (rys. 1) i tylko od 5 do $10 \%$ dotyczy wyspy turbinowej. Wspomniane $120 \mathrm{~km}$ rurociągów tworzą rury stalowe o średnicy od 10 do $400 \mathrm{~mm}$, z których $60 \%$ stanowią rury ze stali nierdzewnych w gatunkach AISI 304L, 316L oraz 904L. W przypadku zaworów, łączna ich liczba wynosi 18000, w tym 14000 w części jądrowej i 4000 turbinowej [12].

Układy bezpieczeństwa i peryferyjne w jądrowym systemie dostarczania pary (NSSS - Nuclear Steam Supply System) są tworzone przez około 60 km rurociągów, w tym 80\% wykonuje się w oparciu o wymagania kodu RCC-M, a pozostałe $20 \%$ - wg norm europejskich i międzynarodowych typu EN lub EN ISO [12]. Z kolei w ramach układów peryferyjnych niezwiązanych z dostarczaniem pary, tylko 45\% rurociągów, które ich tworzą, są wykonywane według wymagań kodu RCC-M, w tym 18\% rurociągów Class 2 oraz 27\% rurociągów Class 3. Rury są wykonywane ze stali niestopowych w gatunkach A 106 Gr B wg ASTM i P265GH wg EN ISO oraz austenitycznych stali nierdzewnych typu AISI 304L / 316L. Zakres stosowanych średnic mieści się w przedziale od 10,3 do $863,60 \mathrm{~mm}(34 ")$.

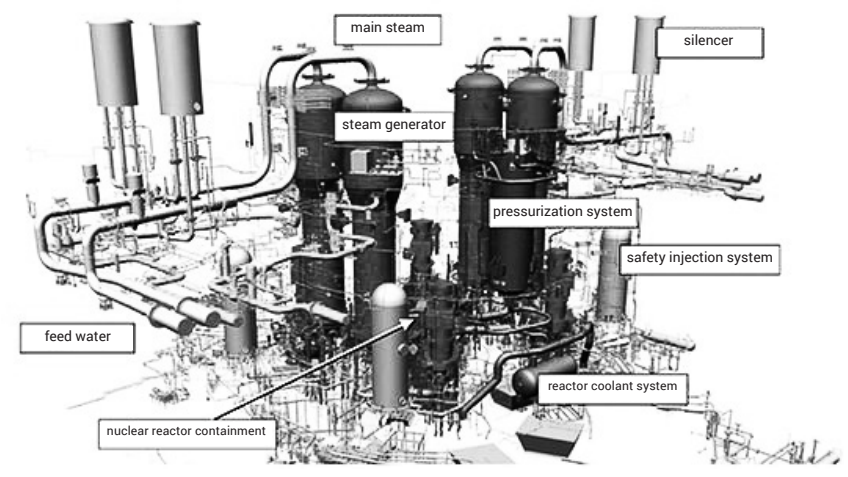

Rys. 1. Układy reaktora EPR, w których rurociągi odgrywają istotną role (Źródło: AREVA)

Fig. 1. EPR reactor systems in which pipelines play an important role (Source: AREVA)

\section{AP1000}

Firma Westinghouse na swojej stronie internetowej [8] podaje, że jedna elektrownia jądrowa wymaga ułożenia 44 mil ( 71 km) rurociągów. W obiegu pierwotnym (rys. 2) rurociąg wylotowy (Outlet Piping) ma średnice 31" (787,4 mm) i grubość ścianki 3,25" (82,55 mm), a powrotny (Inlet Piping) - 22" (558,8 mm) i ściankę 2,56" (65,02 mm). Obydwa te rurociągi są wykonane $z$ austenitycznej stali nierdzewnej SA-376 TP316LN. Z kolei główny rurociąg dostarczania pary charakteryzuje się średnicą 38" (965,2 mm) i jest wykonany z rur bez szwu ze stali węglowej SA-335 Gr P11. Większość pozostałych rurociągów tworzących układy wyspy jądrowej do pełnienia różnych funkcji jest wykonywana ze stali SA-312 TP316N oraz w mniejszym stopniu ze stali SA-312 TP304L. Z ww. stali nierdzewnych są także wykonywane odpowiednie zawory i pompy.

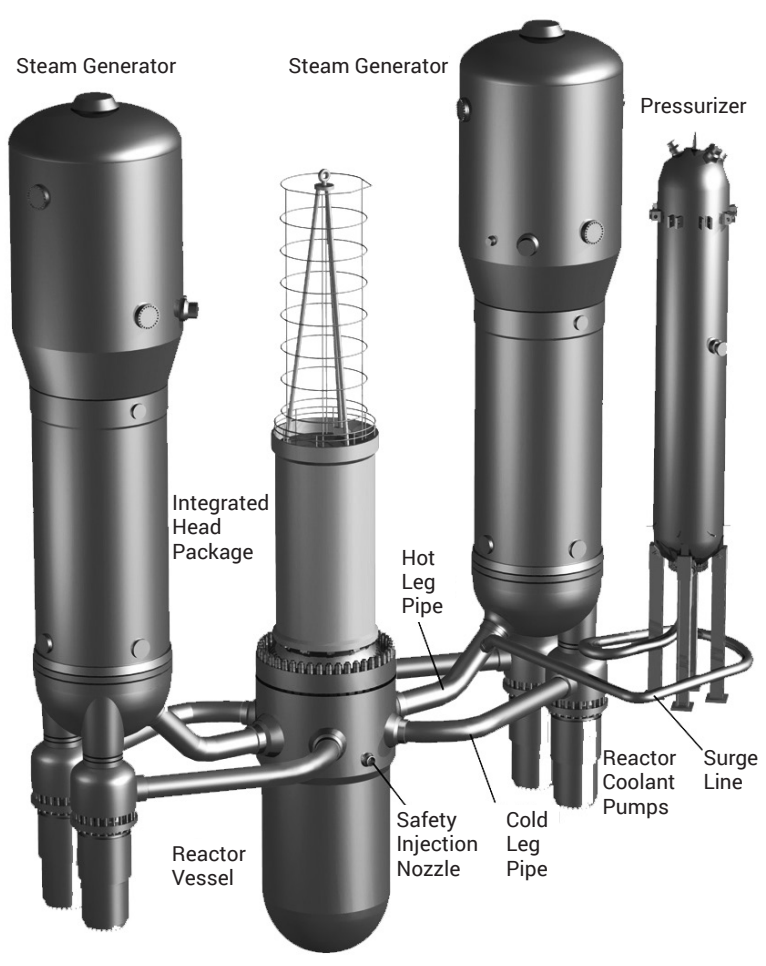

Rys. 2. Schemat obiegu jądrowego reaktora AP1000 [13]

Fig. 2. AP1000 reactor coolant system [13]

\section{ABWR}

W przypadku reaktora ABWR, łączna długość rurociągów w elektrowni jądrowej wynosi 150 km [9]. Podczas ich wykonywania na placu budowy wykonuje się ok. 30000 złączy spawanych. Wytworzona w reaktorze ABWR para jest dostarczana bezpośrednio do turbiny (rys. 3) za pomocą czterech główny rurociągów ze stali węglowej o średnicy 28 " (711,2 mm). Wiele innych instalacji rurowych są wykonywane zarówno ze stali węglowych, jak i austenitycznych stali nierdzewnych ze względu na warunki pracy, a przede wszystkim oddziaływanie korozyjne. Na przykład, w układzie odprowadzania ciepła resztkowego (RHR - Residual Heat Remowal System) rurociągi wysokiego (High Pressure Primary Piping) i niskiego ciśnienia (Low Pressure) obwodu pierwotnego (Class 1 oraz Class 2) są wykonane z rur bez szwu ze stali węglowej SA-333 Gr 6 oraz ze szwem SA-672 Gr C70. Z kolei rurociągi basenu paliwowego Class 3 (Interface to Fuel Pool Piping) tworzą rury ze stali nierdzewnej SA-376 Type 316L, SA-312 Type 316L, SA-358 Type 316L. 


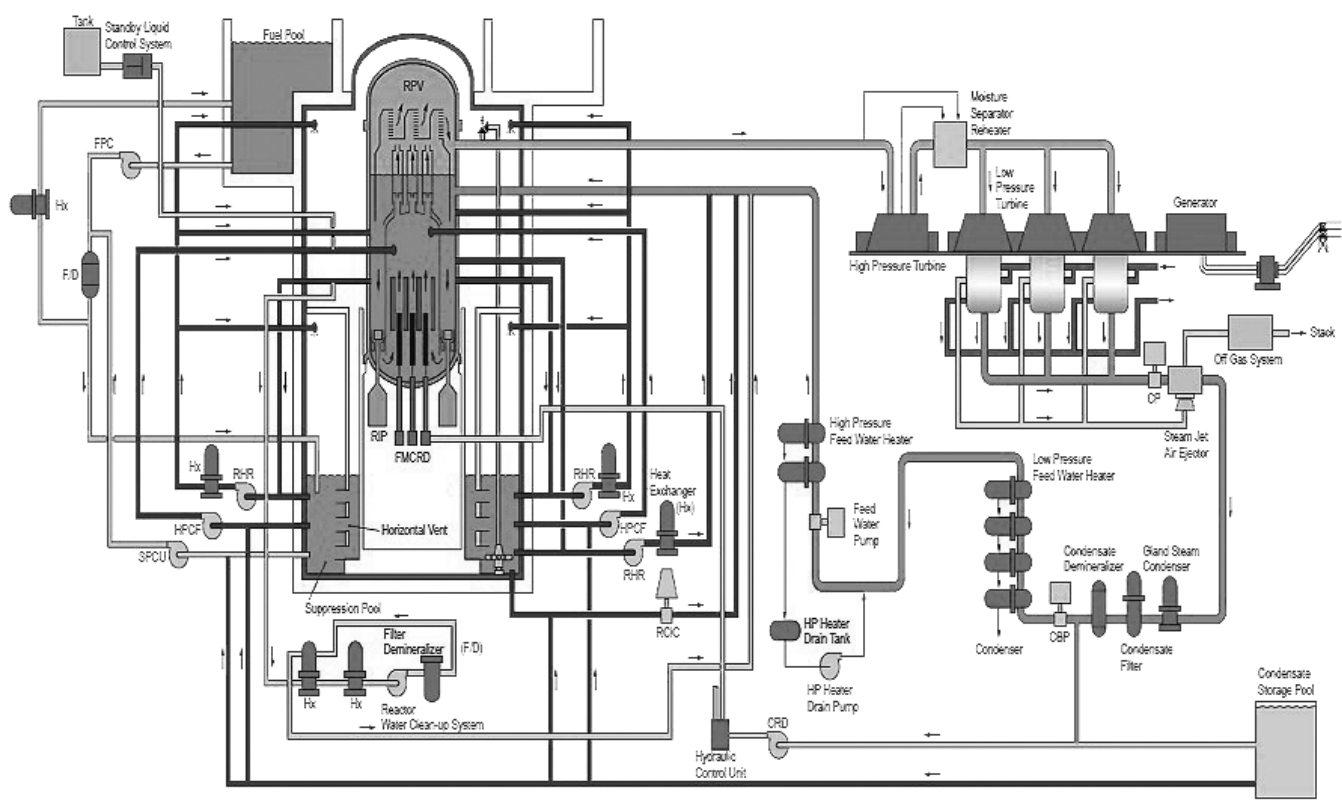

Rys. 3. Schemat przebiegu niektórych rurociągów reaktora ABWR [14]

Fig. 3. ABWR Major Piping Systems [14]

\section{Wnioski}

Elektrownia jądrowa jest szczególnym obiektem przemysłowym, co warunkuje, że zasady projektowania, wytwarzania i odbioru urządzeń, rurociągów i armatury istotnych z punktu widzenia bezpieczeństwa jądrowego są ujęte w specjalnych przepisach i normach. Zarówno w kodzie AFCEN RCC-M, jak i ASME Section III są przedstawione wymagania dotyczące armatury i rurociągów w trzech klasach bezpieczeństwa: Class 1, 2 i 3, które są uzależnione od pełnionej przez nich funkcji i znaczenia dla bezpieczeństwa. W obydwu kodach podkreślono, że klasa komponentów jest określona w specyfikacji technicznej każdego konkretnego urządzenia lub układu, w związku z czym kody te nie definiują, które z poszczególnych urządzeń lub komponentów należą do Class 1, 2 lub 3, lecz zawiera wymagania w zakresie projektowania, wytwarzania i kontroli urządzeń, komponentów i układów zaliczanych do tych klas.

W oparciu o dostępne dane techniczne i dokumentacje projektową reaktorów EPR ${ }^{\mathrm{TM}}$, AP1000 oraz ABWR można stwierdzić, że do wykonania wielu instalacji rurowych przewiduje się stosowanie rur i armatury ze stali węglowych powszechnie stosowanych w elektrowniach konwencjonalnych oraz z austenitycznych stali nierdzewnych typu AISI 304L lub 316L, które są często stosowane do wykonania rurociągów technologicznych także w zakładach chemicznych lub petrochemicznych oraz przemyśle spożywczym. Z przetwarzaniem obydwu tych rodzajów stali (cięciem, gięciem, obróbką mechaniczną i spawaniem) krajowe firmy z branży metalowej powinny bez trudu sobie poradzić, jednak ich udział w budowie pierwszej elektrowni jądrowej w Polsce będzie możliwy tylko pod warunkiem posiadania m.in. odpowiednich systemów zapewnienia jakości stosowanych w branży jądrowej, kwalifıkowanych technologii spawalniczych oraz personelu spawalniczego i badań nieniszczących (NDT) o odpowiednich kwalifikacjach.

\section{Artykuł powstał w ramach projektu współfinansowanego ze środków Ministerstwa Energii w ramach wdrażania energetyki jądrowej w Polsce.}

\section{Literatura}

[1] ASME Boiler and Pressure Vessel Code, Section III: Rules for construction of nuclear facility components, American Society of Mechanical Engineers, New York, 2015

[2] AFCEN RCC-M: Design and Construction Rules for Mechanical Components of PWR Nuclear Islands, 2012 Edition.

[3] Classification of systems, structures and components of a nuclear facility, Guide YVL B.2, STUK, 15 November 2013.

[4] Safety classification of structures, systems and components in nuclear power plants, IAEA Safety Standards Series No. SSG-30, IAEA, Vienna, 2014

[5] Safety of Nuclear Power Plants: Design, IAEA Safety Standards Series No. SSR-2/1 (Rev. 1), IAEA, Vienna, 2016.

[6] Safety Assessment for Facilities and Activities, IAEA Safety Standards Series No. GSR Part 4 (Rev. 1), IAEA, Vienna, 2016.

[7] http://www.boccard.com/en/nuclear-island-auxiliary-systems [31.07.2017]

[8] http://www.westinghousenuclear.com/Why-Nuclear/Jobs [31.07.2017]
[9] N. Kajiyama, K. Hamamura, K. Murayama: Hitachi's Involvement in Nuclear Power Plant Construction in Japan, Hitachi Review, vol. 58, 2009, No. 2

[10] Finland: Olkiluoto 3 Gradually Taking Shape, Nuclear News Letter, AREVA NP Customer Information, November 2007.

[11] J. McIntyre: Hinkley Point C...full steam ahead!, Nuclear Exchange, vol. 10, May 2013, pp. 31-34.

[12] Ph. Malouines, G. Bezdikian: From the Safety Approach of a Nuclear Power Plant, to the Manufacturing and Welding of Mechanical Components in Line with RCC-M Code, Seminarium: Kody, normy i przepisy dotyczące projektowania, wytwarzania oraz systemów zarządzania jakością obowiązujących w przemyśle jądrowym, MG/IS/UDT, Warszawa, 22-24.09.2015.

[13] P. Gaio: AP1000: The PWR Revisited, IAEA International Conference on Opportunities and Challenges for Water Cooled Reactors in the 21 st Century, 27 October 2009.

[14] The ABWR Plant. General Descripcion, GE Energy, USA, December 2006 